\title{
Risk Factors for the Prevalence of Stunting in Young Children and Its Prevention
}

\author{
Desy Linasari* \\ Department of Public Health, Faculty of Medicine \\ Universitas Jenderal Achmad Yani \\ Cimahi, Indonesia \\ *desy.linasari@lecture.unjani.ac.id
}

\begin{abstract}
Nearly 9 millions of Indonesian children suffer from stunting, and Indonesia is ranked the 5th in the world for the highest number of short children. Indonesia has made some progress towards achieving the target for stunting, but $30.8 \%$ of children under 5 years of age are still affected, which is higher than the average for the Asia region $(\mathbf{2 1 . 8 \%})$. The study was aimed to know the risk factors related to the prevalence of stunting in children under 5 years old. The study used crosssectional study with sample taking technique employing consecutive sampling. The study was done at the Community Health Center in Cibeber, Cimahi with 116 children under 5 years old. The data were analysed with data analysis using simple regression logistic. The study concluded that the highest risk factor for stunting to happen in children was the maternal knowledge with the OR score of 3,03 . Stunting prevalence was affected by the mother's behaviour in parenting the children. Attitudes and knowledge are the factors affecting behaviour, therefore stunting prevention can be done by improving the knowledge of the mother on nutrition and good parenting.
\end{abstract}

Keywords-stunting, knowledge, risk factor

\section{INTRODUCTION}

Stunting is the impaired growth and development that children experience from poor nutrition, repeated infection, and inadequate psychosocial stimulation. Children are defined as stunted if their height-for-age is more than two standard deviations below the WHO Child Growth Standards median [1]. Stunting is the result of long-term nutritional deprivation and often results in delayed mental development, poor school performance and reduced intellectual capacity. This in turn affects economic productivity at national level. Women of short stature are at greater risk for obstetric complications because of a smaller pelvis. Small women are at greater risk of delivering an infant with low birth weight, contributing to the intergenerational cycle of malnutrition, as infants of low birth weight or retarded intrauterine growth tend be smaller as adults [2].

Stunting is a double burden of malnutrition in Indonesia. Firstly, it reduces productivity, and the second one is the increasing risk of non-communicable diseases such as heart disease and Diabetes Mellitus The World Bank estimates that losses due to malnutrition are about 2.5 percent of the country's gross domestic product (GDP). The population of Indonesia is dominated by young people with more than half of the population, which should be a large potential workforce and productive population. This condition will become a burden if the productive population works in unhealthy conditions, which will claim a higher cost of national health insurance $[3,4]$. Nutrition-inadequacy related GDP loss reaches $12 \%$ in poor countries in Asia and Africa. From 2050 projection, it is expected that there GDP losses will drop to only $6 \%$ with improved nutrition as implemented in Latin America [5].

In a study conducted in 137 developing countries, it was revealed that 44.1 million children under 2 years of age were stunted, which is equivalent to $36 \%$ of the population of children aged 2 years. South Asia and sub-Saharan Africa show the largest percentage of stunting in all regions. The highest risk factors for stunting in this study were small for gestational age, unimproved environment and childhood diarrhea [6]. Factors which are related to the incidence of stunting in subSaharan Africa include low maternal education, age of the child, and sex of the child wealth index, prolonged duration of Breast Feeding, low birth weight, mother's age $(<20$ years $)$, source of drinking water, diarrhoel, and place of residence [6].

The problem with nutrition became a global priority and the target of Millenium Development Goals (MDG) until 2015. This agreement continued and was included in Sustainable Development Goals (SDGs) up to year 2030. Scaling Up Nutrition (SUN movement) is a movement under the coordination of Secretary General of The UN to describe the continuance of the agreement in MDGs related to the problem of nutrition and food. The goal of SUN movement is to reduce the problems of poor nutrition status of children, focusing on the first 1000 days of life (1000 HPK) [7].

The incidence of stunting are related to many factors, which demand multi-sector cooperation to minimize the incidence of stunting in Indonesia. Some of the stunting-related factors are male sex, premature birth, short birth length, nonexclusive breastfeeding for the first 6 months, short maternal height, low maternal education, low household socio-economic status, living in a household with unimproved latrines and untreated 
drinking water, poor access to healthcare, and living in rural areas [8]. Therefore, this study was aimed at finding the prevalence of stunting and factors causing stunting in children of 0- 59 months in the Cibeber Community Health Center, Cimahi.

\section{METHODS}

The study design used in this study was cross sectional study with quantitative approach. The study used primary data by distributing questionnaires to the mothers with children under five years, and secondary data from "Buku Kesehatan Ibu dan Anak (KIA)" (A book on maternal and children's Health) for body-height and body-weight data. The time of data collection started in November 2020 to January 2021 in the area of the Community Health Center in Cibeber. During the data taking, the researcher applied the health protocol, which was to wear self-protecting equipment, consisting of an apron, face shield, medical mask and gloves, keeping the distance with the respondents during the interview. The subject of the study was the children under 5 years of 0-60 months of age in the area of the Community Health Center in Cibeber, with the mothers of children under five years agreeing and approving their children to participate in the study as the respondents.

The determination of the sample size was based on a Hypothesis test for two population proportions (two-sided test) with P-Value $5 \%$ and power of $90 \%$, therefore the minimum number of samples was 60 respondents. As the data were collected during the Covid-19 pandemic, the samples taking method employed during the study was consecutive sampling. Consecutive sampling is a non-randomized sampling taking method in which the respondents fulfilling the inclusive criteria are taken as the study sample until the number of samples in this study is met.

The data analysis used in this study was analysis descriptive and analysis simple logistic regression. Analysis descriptive is to describe the characteristics of study variables, numeric data variables are presented by mean, median, deviation standard, and minimum and maximum values. Categorical data variables are presented by proportion or percentage. After the analysis descriptive is done, the analysis is continued to the simple logistic regression. From the analysis result of simple logistic regression, the Odds Ratio is derived to know the risk factor of stunting prevalence. This study was conducted after receiving the ethics approval from Medicine Ethics Commission of Medicine Faculty of Universitas Jenderal Achmad Yani no 051/UM2.11/2020.

\section{RESULTS}

The number of children in this research was 116 , consisting of 55 children under five years with stunting and 61 children under five years with normal body height. The description of the characteristics of the study variables can be seen in Table 1. For the age variables, the researcher classified them into 3 groups; children of 0-11 months, 12-35 months and 36-59 months.
TABLE I. THE CHARACTERISTICS OF THE CHILDREN UNDER FIVE YEARS

\begin{tabular}{|l|l|l|}
\hline \multicolumn{1}{|c|}{ Variable } & Number & Percentage \\
\hline Age (Month) & & \\
$12-35$ & 71 & 61,2 \\
$36-59 \quad$ Sex & 12 & 28,4 \\
Male & 63 & 10,3 \\
Female & 53 & 54,3 \\
Body Height/Age & 55 & 45,7 \\
Stunted & 61 & 47,4 \\
Normal & & 52,6 \\
\hline Exclusive mother's milk & 91 & \\
Yes No Immunization & 25 & 78,4 \\
No & 109 & 21,6 \\
\hline Complete & 7 & 94,0 \\
Incomplete & 110 & 6,0 \\
\hline Vitamin A & 6 & 94,8 \\
Yes No &
\end{tabular}

The respondents of the study based on the age of $0-11,12-$ 35 and 36-59 months were $61,2 \%, 28,4 \%$, and $10,3 \%$ consecutively. In this study, there were more male children than the female ones. From the perspective of exclusive mother's milk treatment, and vitamin A administration, most of the respondents were good enough with the percentage of more than $70 \%$.

TABLE II. MOTHERS CHARACTERISTICS

\begin{tabular}{|c|l|l|}
\hline Variable & Number & Percentage \\
\hline Maternal education & & \\
Low & 45 & 38,8 \\
High & 71 & 61,2 \\
\hline Employment & & \\
Employed & 28 & 24,1 \\
Unemployed & 88 & 78,4 \\
\hline Number of children & & \\
$\leq 2$ children & 84 & 72,4 \\
2 children & 32 & 27,6 \\
\hline Knowledge & 33 & 28,4 \\
Poor Good & 83 & 71,6 \\
\hline
\end{tabular}

Based on the Table 2, characteristics of the mothers it can be seen that number of mothers with low education was $36,8 \%$ whilst those with high education were $61,2 \%$. In respect of knowledge, $71,6 \%$ of whom had good knowledge. In terms of work, in average, there were more mothers with the children under five years old who were not working than those who were working.

Table 3 demonstrates the risk factors associated with the stunting prevalence in children under five years in the Community Health Center in Cibeber, Cimahi. The stunting prevalence varies according to age group, the stunting age lied mostly in the younger age groups. The percentage of stunting in children at the age of $0-11$ months was $52.1 \%, 12-35$ months was $39.1 \%$ and those aged $36-59$ months were $41.7 \%$. The 0 - 
11 month's age group had a risk of stunting by 1 , which was higher than the 36-59 months age group. The group between 12-35 months age and 36-59 month had almost the same risk of stunting.

TABLE III. Stunting PreVAlENCE RISK FACTORS

\begin{tabular}{|l|l|l|l|}
\hline Variable & Stunted & Normal & OR \\
\hline $\begin{array}{l}\text { Age }(\text { month }) \\
0-11\end{array}$ & $37(52,1 \%)$ & $34(47,9 \%)$ & 1,52 \\
$12-35$ & $13(39,4 \%)$ & $20(60,6 \%)$ & 0,91 \\
$36-59 \quad$ Sex & $5(41,7 \%)$ & $7(58,3 \%)$ & Reff \\
\hline $\begin{array}{l}\text { Male } \\
\text { Female }\end{array}$ & $36(57,1 \%)$ & $27(42,9 \%)$ & 2,39 \\
\hline $\begin{array}{l}\text { Immunization } \\
\text { Yes }\end{array}$ & $19(35,8 \%)$ & $34(64,2 \%)$ & Reff \\
No & $52(47,7 \%)$ & $57(52,3 \%)$ & 1,22 \\
\hline $\begin{array}{l}\text { Yes } \\
\text { No }\end{array}$ & $3(42,9 \%)$ & $4(57,1 \%)$ & Reff \\
\hline $\begin{array}{l}\text { Education } \\
\text { Low }\end{array}$ & $51(46,4 \%)$ & $59(53,6 \%)$ & 0,43 \\
High & $4(66,7 \%)$ & $2(33,3 \%)$ & Reff \\
\hline $\begin{array}{l}\text { Employment } \\
\text { Employed }\end{array}$ & $26(57,8 \%)$ & $19(42,2 \%)$ & 1,98 \\
Unemployed & $15(53,6 \%)$ & $13(46,4 \%)$ & 1,38 \\
\hline $\begin{array}{l}\text { Number of Children } \\
\leq 2 \text { children }\end{array}$ & $40(45,5 \%)$ & $48(54,5 \%)$ & Reff \\
\hline$>2$ children & $42(50,0 \%)$ & $42(50,0 \%)$ & 1,46 \\
\hline $\begin{array}{l}\text { Knowledge } \\
\text { goor }\end{array}$ & $13(40,6 \%)$ & $19(59,4 \%)$ & Reff \\
\hline \multicolumn{2}{|c|}{$22(66,7 \%)$} & $11(33,3 \%)$ & 3,03 \\
\hline
\end{tabular}

The stunting prevalence differs based on sex, with boys having a higher percentage than girls. The percentage of boys with stunting was $57.1 \%$ while the percentage of girls was $35.8 \%$. In terms of risk factors, boys had a risk factor of 2.4 times higher for stunting than girls. More girls had a normal height than boys.

In immunized children, $47.7 \%$ of children under five years old were stunting while $52.3 \%$ of children under five years old were normal. The risk factors in immunized children were slightly higher than those without. Immunized children had a risk factor of 1.22 times compared to children who were not immunized.

The stunting prevalence was different according to the status of vitamin A. The stunted children who received vitamin A were $46.4 \%$, while the stunted children who did not get vitamin A were $66.7 \%$. The children who got vitamin A had a lower risk than those who did not get vitamin A. The children who got vitamin A had a risk of 0.43 times compared to those who did not receive vitamin $A$. OR of the children who received Vitamin A was less than 1 , therefore vitamin $\mathrm{A}$ is a protective factor or a factor that can prevent stunting in children.

The stunting prevalence also varied based on maternal characteristics. Based on maternal education, mothers with low education tended to have stunted children compared to those with high education. Mothers with low education had a risk of having their children stunted by 1.98 times compared to those with high education. Working mothers had a higher risk of getting their children stunted, which was 1.38 times compared to those who did not work.

$50 \%$ of the stunted children came from the mothers with one child, while the other $50 \%$ were not stunted. $40,6 \%$ of the children coming from the mothers with two children or more were stunted, while $59,4 \%$ of whom were not stunted. The mothers with only 1 child had a risk of 1.46 compared to the mothers who had two or more children to have a stunted child.

The stunting prevalence in mothers with poor and good knowledge was different, that the mothers whose knowledge was poor were prone to have more stunted children than those with good knowledge. Stunted children with mothers with poor knowledge were $66.7 \%$ and those with good knowledge were $39.8 \%$. The mothers with poor knowledge had a risk of 3.03 higher than those with good knowledge of the stunting prevalence in children under five years old. From all the analyses in Table 3, the knowledge factor was the greatest risk factor associated with the stunting prevalence in children under five years old in the Community Health Center in Cibeber, Cimahi.

\section{DISCUSSION}

In this study, the percentage of stunting found in the children at the age of 0-11 months made the highest percentage with $52,1 \%$, and stunting prevalence went down along with age. The fact that the children suffering from stunting when they are under than 1 year old can be related to the assumption that stunting takes place in the pre-conception period. The preconception period will affect the health of the fetus in the womb of the mother.

Maternal nutrition during pregnancy significantly contribute to stunting prevention. Bone ossification approximately begins in the sixth weeks of embryonic development and continues to the end of pregnancy. Referring to a study conducted in West Java, it was suggested that underweight mothers had 13.2 times the risk of giving birth to a stunting baby [9]. In addition to the condition of underweight mothers, stunting will be 5 times higher in anemic mothers, and Indonesia still has a fairly high prevalence of anemic mothers [10]. The results of this study also suggested that as the age increases, the incidence of stunting decreases. It can be seen that early detection of stunting cases and nutritional intervention can reverse stunting to normal [11].

The children in the vicinity of the Community Health Center in Cibeber who were included as respondents in the study consumed vitamin A regularly. The results of this study found that vitamin A was a protective factor for stunting, or a factor that lowered the risk for stunting in children. Regular vitamin A administration is held at the integrated service post (posyandu) every February and August. Infants aged 6-11 months are given vitamin $\mathrm{A}$ in blue capsules at a dose of $100,000 \mathrm{IU}$ and babies aged 12-59 months are given vitamin A in red capsules at a dose of 200,000 IU. 
Children with the problem of vitamin A deficiency will have a tendency to suffer from stunting as during childhood vitamin A affects cell growth so that if there is a deficiency, it can damage the immune system and can increase the risk of infections such as measles and diarrhea. 27 In addition to the macronutrient elements that the body needs, micronutrient elements are also required by the body. Micronutrient elements needed by the body include Vitamin A, Vitamin C, Iron, zinc and calcium. Vitamin A also plays a role in accelerating bone growth for the prevention of blindness. Administration of vitamin $\mathrm{A}$ is one of the most effective interventions to prevent stunting as it is cost effective. Besides giving Vitamin A to prevent diarrhea, applying zinc supplements is also very helpful in reducing the prevalence of diarrhea in children and strengthening the immune system [12-14]

Vitamin $\mathrm{A}$ is the most dominant factor that can affect a child's height. Children treated with vitamin A demonstrate a 2.5 times higher chance than children who are not treated with vitamin A. Vitamin A is required by various body tissues and metabolic processes, in addition vitamin A can reduce the incidence of morbidity and mortality. Vitamin A plays its role in the prevention of anemia and stunting 0 People in developing countries like Indonesia derive most of their vitamin A from provitamin A carotenoids, of which $\beta$ carotene is the most important. Vitamin A is fat soluble vitamin that can help the absorption and metabolism of iron for the formation of erythrocytes. Low vitamin A status will make iron deposits unable to be utilized for the process of erythropoiesis [15].

Increasing mother's knowledge, beliefs and behavior are the keys to stunting prevention. This has also consistently reduced the incidence of a child suffering from stunting mothers in Indonesia are generally the primary caregivers for children and that maternal education is associated with protective behaviors including increased visits to the local health post or posyandu, access and use of closed latrines, receipt of childhood immunizations, and receipt of vitamin A capsules. The way a mother raises her child reflects the knowledge and ability of the mother in practices that support the growth and development of the child [16].

Maternal knowledge is the highest risk for stunting in this study. A good level of knowledge will make a mother wise and thoughtful in selecting nutritious foods to support the children's growth and can make the right decision when the child is sick. Formal education of a mother is needed to add knowledge in order to regulate and comprehend the nutritional needs of family members. Mothers with low education have low knowledge, and parenting habits are obtained from their parents and neighbors who possibly also bear no proper education background and have no experience which will be an inhibiting factor in carrying out maximum childcare, which result in stunting [17].

Management and prevention of stunting is run through specific interventions and sensitive interventions on the target of the first 1000 days of a child's life until the age of 6 years. The interventions to involve are the fulfillment of adequate nutrition, complete monitoring of growth and development, sufficient and affectionate stimulation, and a clean environment. Specific interventions that can be taken are to encourage and continue exclusive breastfeeding until the age of 23 months by adding complementary foods from 6 months of age, giving $\mathrm{Fe}$ and folic acid tablets to pregnant and breastfeeding women, prevention and treatment of malaria in pregnant women, infants and children. Interventions in children can be done by administering vitamin A, deworming, zinc supplementation, overcoming iodine deficiency, complete, as well as prevention and treatment of diarrhea. Sensitive interventions include PHBS interventions such as washing hands and increasing access to clean water, psycho-social stimulation of infants and children, family planning and public health insurance $[18,19]$.

\section{CONCLUSION}

The dominant factors associated with stunting prevalence are education, gender, and knowledge, whereas Vitamin A is a factor that reduces the risk of stunting. Based on the results of this study, it is suggested that counseling be provided at the integrated service post (posyandu) to raise maternal knowledge on nutrition. The role of Community Health Centre and cadres is to encourage the community to visit the Community Health Center to follow regular monitoring of the children so that if a stunting case is found, it can be intervened early so that the child can grow optimally.

\section{ACKNOWLEDGMENT}

This work was supported by a grant from LPPM Jenderal Achmad Yani University.

\section{REFERENCES}

[1] World Health Organization, "Stunting in a nutshell," 2015. [Online]. Retrieved from: https://www.who.int/news/item/19-11-2015-stunting-ina-nutshell [cited 2021 Apr 26]

[2] World health Organization, "Nutrition Landscape Information system (NLIS) Country Profile Indicators: Interpretation Guide," Nutrition Landacape Information System (NLIS), 2012, 1-2 p. [Online]. Retrieved from: https://www.who.int/nutrition/nlis_interpretation_guide.pdf

[3] UNICEF, "The "double burden" of malnutrition in Indonesia," 2018 [Online]. Retrieved from: https://www.unicef.org/indonesia/nutrition [cited 2021 Apr 25].

[4] T. Vaivada, N. Akseer, S. Akseer, A. Somaskandan, M. Stefopulos, an Z.A. Bhutta, "Stunting in Childhood: an overview of global burden, trends, determinants, and drivers of decline," The American journal of clinical nutrition, vol. 112, no. (Supplement_2), pp. 777S-791S, 2020.

[5] S. Horton and R.H. Steckel, Global economic losses attributable to malnutrition 1900- 2000 and projections to 2050. Cambridge: Cambridge Univ Press, 2011, pp. 247-72. [Online]. Retrieved from: https://www.cambridge.org/core/books/how-much-have-globalproblems-cost-the-world/malnutrition-global-economic-lossesattributable-to-malnutrition-19002000-and-projections-to2050/0735631A8EC48B88F6CD27378D97102B

[6] G. Danaei, K.G. Andrews, C.R. Sudfeld, G. Fink, D.C. McCoy, E. Peet .. and W.W. Fawzi, "Risk factors for childhood stunting in 137 
developing countries: a comparative risk assessment analysis at global, regional, and country levels," PLoS medicine, vol. 13, no. (11), pp. 1-18, 2016.

[7] BKKBN, Bahan penyuluhan bina keluarga balita bagi kader 1000 HPK. Jakarta: BKKBN, vol. 53, 2013, pp. 1689-1699.

[8] T. Beal, A. Tumilowicz, A. Sutrisna, D. Izwardy, and L.M. Neufeld, "A review of child stunting determinants in Indonesia," Maternal \& child nutrition, vol. 14, no. (4), pp. 1-10, 2018.

[9] H. Fitriani and P. Nurdiana, "Risk Factors of Maternal Nutrition Status During Pregnancy to Stunting in Toddlers Aged 12-59 Months," Jurnal Keperawatan Padjadjaran, vol. 8, no. (2), pp. 183-191, 2020.

[10] S.T. Tampy, H.W. Nugroho, and R. Syuadzah, "Association between Maternal Anemia with Stunting Incidence among Newborns in Surakarta, Central Java," in Proceedings of 7th International Conference on Public Health, 18-19 November 2020.

[11] C.R. Titaley, I. Ariawan, D. Hapsari, A. Muasyaroh, and M.J. Dibley, "Determinants of the stunting of children under two years old in Indonesia: a multilevel analysis of the 2013 Indonesia Basic Health Survey," Nutrients, vol. 11, no. (5), p. 1106, 2019.

[12] A. Winterfeld, Improving child nutrition. Vol. 18, USA: NCSL legisbrief, 2010, pp. 1-2.

[13] T. Mahmudiono, S. Sumarmi, and R.R. Rosenkranz, "Household dietary diversity and child stunting in East Java, Indonesia," Asia Pac J Clin Nutr., vol. 26, no. (2), pp. 317-25, 2017.
[14] UNICEF, "Tracking Progress on Child and Maternal Nutrition," A survival and development priority, 2009, NY 10017. [Online]. Retrieved from:

http://www.unicef.org/spanish/media/files/Tracking Progress on Child and_Maternal_Nutrition_EN_110309.pdf

[15] B.Y. Simanjuntak, M. Haya, D. Suryani, and C.A. Ahmad, "Early inititation of breastfeeding and vitamin a supplementation with nutritional status of children aged 6-59 months," Kesmas: Jurnal Kesehatan Masyarakat Nasional (National Public Health Journal), vol. 12, no. (3), pp. 107-113, 2018

[16] C. Hall, C. Bennett, B. Crookston, K. Dearden, M. Hasan, M. Linehan, ... and J. West, "Maternal knowledge of stunting in rural Indonesia," International Journal of Child Health and Nutrition, vol. 7, no. (4), pp. 139-145, 2018.

[17] S.S. Nasution and F. Oktavinola, "mother's knowledge dan attitude about stunting of children in namorambe distric," Abdimas talenta: Jurnal Pengabdian Kepada Masyarakat, vol. 4, no. (1), pp. 61-65, 2019.

[18] TNP2K, "100 kabupaten/kota prioritas untuk intervensi anak kerdil," [Online]. Retrieved from: http://www.tnp2k.go.id/images/uploads/downloads/Binder Volume1.pd f

[19] Kementerian Desa Pembangunan Daerah Tertinggal dan Transmigrasi, Buku saku desa dalam penanganan stunting. Jakarta: Buku Saku Desa Dalam Penanganan Stunting, 2017, p. 42. 